\title{
Eskatologie in die boek Sefanja ${ }^{1}$
}

J D Kirkpatrick

\section{ABSTRACT}

Eschatology in Zephaniah

That the book Zephaniah is of an eschatological nature, is posed as a hypothesis. This means that the judgement and salvation themes in the book occur in such a relationship that it can be described as eschatology. Judgement in Zephaniah has the characteristics of a radical and final judgement with which the past is relativised. The judgement thus implies the end of a period. The salvation promises create the expectation of a new period brought about by Jahwe. The radical judgement words and promises of salvation are combined in such a manner that separately and combined they form part of the eschatological concepts of the Old Testament. The eschatological theme does not only appear in those sections that deal with the Jom Jahwe. The manner in which Jerusalem functions as focal point, the place of the words of condemnation against the foreign nations, the employment of the remnant theme and the interaction between future expectations and criticism on social, political and cultic aspects of life, give the book Zephaniah a prominent eschatological character. The book Zephaniah represents a perspective on the future in which Jahwe himself through judgment will terminate the old period and create a new period which wil be real and concrete. In the description of the nature of eschatology in the Old Testament, the book Zephaniah with its characteristic eschatological nature, should enjoy a more prominent place.

Sedert Gressmann ${ }^{2}$ in 1905 die eerste keer die begrip eskatologie in verband met Ou-Testamentiese studies gebruik het, word die gesprek oor eskatologie in die $\mathrm{Ou}$ Testament gekenmerk deur ' $n$ Babelse verwarring ten opsigte van terminologie. Gressmann kon die term eskatologie probleemloos uit die Dogmatiek van sy tyd oorneem omdat hy daarmee verwys het na die dinge wat "mit dem Weltende und der Welterneuerung" te make het.

Die term eskatologie is egter sedert Gressmann nie net in dié eng sin van die woord gebruik nie. Dit word ook in 'n breër sin, as beskrywing van 'n toekomsverwagting wat binne die geskiedenis sou realiseer ${ }^{3}$, gebruik. Dit is te begrype dat 
daar dus verwarring sou ontstaan oor wat as eskatologie gereken moet word en wat nie.

'n Oorsig oor die literatuur waarin eskatologieë van die Ou Testament ter sprake is, laat die indruk van soveel hoofde, soveel eskatologieë. Wanke verwys daarna as "eine aussichtslose Terminologische Verwirrung"4. Die een na die ander skrywer oor die eskatologie in die Ou Testament maak van hierdie terminologiese verwarring melding. Preuss het 'n reeks artikels oor die eskatologie in die $\mathrm{Ou}$ Testament byeengebring wat verteenwoordigend is van die navorsing vir die tydperk 1929-1974. In bykans elkeen van die bydraes word daar melding gemaak van die probleem ten opsigte van terminologie 5 .

Verskillende faktore het 'n rol gespeel om hierdie verwarring te veroorsaak. Vriezen herlei die probleem na die verskil wat daar tussen die Geesteswetenskappe en Natuurwetenskappe bestaan. Volgens hom maak die komplekse aard van die Geesteswetenskap dit onmoontlik om met eksakte "Formeln und Sigla" te werk en daarom is 'n eenvoudige klassifikasie van verskynsels nie so maklik te bereik nie.

Die feit dat die begrip eskatologie sy oorsprong in die Dogmatiek het en ook in die vakgebied Nuwe Testament prominent figureer, het waarskynlik meer te make met die verwarring as die verskil tussen Geestes- en Natuurwetenskappe. Dit is begryplik dat dieselfde terminologie deur die verskillende dissiplines van die teologie benut sal moet word. Wanneer die begrip egter ten opsigte van die OuTestamentiese literatuur gebruik word, het dit ongelukkig telkens gebeur dat betekenis in die Ou Testament ingedra is wat nie in die Ou Testament self steun vind nie. Dit is veral problematies waar die etimologie van die begrip eschaton as uitgangspunt geneem word vir die behandeling van 'n leerstuk wat handel oor die dinge aan die einde van die geskiedenis. Hiervolgens hou eskatologie met "Lehre von den 'Letzte Dingen', d.h. von dem Letzten, dem Ausgang, dem Ende"6 verband. Die standpunt sou beteken dat eskatologie bykans nie in die Ou Testament voorkom nie. Von Rad ${ }^{7}$ wys daarop dat 'n duur prys vir so 'n eng definisie betaal word: "The most outstanding element in the prophetic message is left without proper explanation and without name".

Alhoewel Preuss ${ }^{8}$ korrek is wannneer hy opmerk dat die aspek van terminologie nie as die "wirklich entscheidende" gereken kan word nie, sou dit tog op terminologiese slordigheid dui indien 'n term wat reeds so 'n veelkantigheid vertoon, benut word sonder om noukeuriger te omskryf wat daarmee bedoel word. Die terminologiese verwarring werk stremmend in op die gesprek oor die eskatologie en die term eskatologie dreig om onbruikbaar te raak. Dié verwarring sal net verder uitbrei as ons nou probeer om 'n nuwe term te munt vir die verskynsel in die profetiese literatuur wat tradisioneel eskatologie genoem word. Die blote skep van 
nuwe terminologie gaan nie die probleem van wat die kenmerke van eskatologie is en watter tekste eskatologies interpreteer kan word, oplos nie. Om die term geheel en al te probeer vermy ${ }^{9}$, maak 'n sinvolle gesprek oor die verskynsel wat tradisioneel deur ander eskatologie genoem word, baie moeilik.

In die lig hiervan is dit begryplik dat daar iets van 'n konsensus onder geleerdes ontwikkel het wat daarop neerkom dat elkeen wat oor die eskatologie handel, telkens duidelik moet maak met watter inhoud hy/sy die begrip eskatologie vul. Uit al die publikasies oor die eskatologie is dit af te lei dat dit terminologies minder verwarring sou veroorsaak indien die navorsers, wat op die toekomsverwagting in die Ou Testament fokus, ter aanvang uitspel aan watter kriteria 'n teks moet voldoen alvorens dit as eskatologies gereken kan word. Die feit dat sommige tekste deur die een as eskatologies en deur die ander as nie-eskatologies beskou word, sou dan wetenskaplik makliker hanteer kon word deurdat elkeen aan sy eie reëls getoets kon word. 'n Koherente uiteensetting van die kenmerke van eskatologiese tekste sou kon help om groter noukeurigheid in die gesprek oor eskatologie te verkry. Die verwarring is nie in die eerste plek te wyte aan die gebruik van die term "eskatologie" nie, maar aan die onnoukeurige aanwending daarvan.

Dit moet dus aanvaar word dat die begrip eskatologie vir die navorsing oor die profetiese literatuur onontbeerlik is. Die term is, soos Von Rad ${ }^{10}$ dit stel, "controversial but unavoidable". Deur dié term te gebruik vind 'n afgrensing na twee kante toe plaas. Enersyds word dit onderskei van 'n algemene toekomsverwagting en andersyds van die latere apokaliptiek. Eskatologie word nie beskou as 'n verskynsel wat die eerste keer by die profete aangetref word nie en het 'n lang geskiedenis nadat die profete al van die toneel verdwyn het.

Die blote feit dat geleerdes voortgaan om van eskatologie in die Ou Testament te praat ten spyte van al die probleme wat die terminologie betref, is alreeds ' $n$ aanduiding van ' $n$ bepaalde soort toekomsverwagting wat nie genoegsaam met woorde soos belofte, hoop of toekomsverwagting beskryf kan word nie. Die term eskatologie maak dit moontlik om binne die groot veld van toekomsverwagting te onderskei tussen 'n toekomsverwagting met 'n bepaalde struktuur (eskatologie) en toekomsverwagting in die algemeen. Dit was veral Vriezen wat, met sy indeling van die eskatologie in verskillende opeenvolgende periodes in die geskiedenis, dit moontlik gemaak het om van verskillende soorte eskatologie te kon praat. Daarmee is die deur geopen vir 'n duideliker definisie van eskatologie in die $\mathrm{Ou}$ Testament. Sodoende het die konsep aan kontoer gewen en kan daar 'n poging aangewend word om eskatologie te definieer. Dit kan van groot waarde wees om die algemene troebelheid op te klaar. 
Met al die beperkinge wat tipies van definisies is in ag genome, meen ek tog dat ' $n$ poging om tot 'n definisie te kom, geregverdig is. Daaruit kan die essensiële van 'n saak afgelees word en 'n poging aangewend word om die wesenlike wat deurgaans in eskatologie aanwesig is, te beskryf. Die soeke na dié wesenlike kom veelvuldig voor in die publikasies oor die eskatologie in die Ou Testament. Die bedoeling is nie om hier 'n oorsig oor die navorsing te gee nie'1, maar eerder om uit die bestaande navorsing vas te stel watter aspekte in 'n definisie van eskatologie opgeneem behoort te word. Die verwysings is daarom ook eerder verteenwoordigend as volledig. Dit is waarskynlik nie moontlik om 'n verskynsel so gevarieerd soos eskatologie met 'n formule-agtige definisie eksak te beskryf nie. Wat ek vervolgens formuleer is 'n poging tot 'n stipulatiewe definisie waarin die verskillende elemente wat deel uitmaak van die konsep "eskatologie", opgeneem word. Die verskillende elemente blyk nie uitsluitend van aard te wees nie en kan komplementerend in 'n stipulatiewe definisie opgeneem word.

\section{Die eskatologiese handeling is Jahwehandeling}

Terwyl dit wesenlik van die eskatologie is om die nuwe te verwag wat finaal 'n einde makk aan die oue, word die verwagting nie op gebeure as sodanig gerig nie, maar op die koms van Jahwe self. Dit is veral Preuss ${ }^{12}$ wat dit as die bepalende faktor vir die Ou-Testamentiese eskatologie hanteer. Dit is vir hom van kardinale belang dat dit om 'n "Jahweerwartung" gaan. Eskatologie het alles te make met die persoonlike ingrype van God en die verwagting dat die heil uitsluitlik deur Jahwe self verwerklik sal word. Die nuwe tyd wat moet aanbreek, word dus nie gesien as die eindresultaat van 'n immanente ontwikkeling wat op eie stoom die nuwe tydvak oplewer nie. Raitt 13 beskou tereg "the freedom of God" as 'n basiese vertrekpunt in die eskatologie wat by die profete aangetref word. Die koningskap van Jahwe is daarom 'n prominente tema in die eskatologie. In die eskatologiese verwagting leef die beeld van God wat aktief en rigtinggewend by die geskiedenis betrokke is.

\section{Jahwehandeling in 'n nuwe tydvak}

Profetiese eskatologie het te make met 'n verwagting wat op die aanbreek van 'n nuwe tydvak gerig is. Te midde van die veelvoud beskrywings is die aspek van die nuwe 'n element wat baie algemeen beklemtoon word.

In Lindblom ${ }^{14}$ se skema van twee tydvakke, wat volgens hom wesenlik aan die eskatologie is, kom die aspek van die nuwe sterk na vore. Dit is 'n "new order" 
wat die konstituerende element van die eskatologie uitmaak. Daar kan van eskatologie gepraat word wanneer die profete op so 'n wyse oor die toekoms praat dat "etwas neues und ganz anderes" verwag word en sprake "von einem neuen Zeitalter mit radikal veränderten Verhältnissen" is. Vir Fohrer neem die profetiese eskatologie met Deuterojesaja 'n aanvang omdat die verwagting van 'n nuwe tydvak in die betrokke gedeeltes prominent is. Gross ${ }^{15}$ definieer eskatologie as "...einer Wende im gegenwärtigen Lauf der Geschichte, von einem wesenlich neuen, veränderten Zustand der Dingen...". Dingermann ${ }^{16}$ beskryf hierdie "new order" met woorde soos "neuen Zustand" en "etwas ganz anderem" en Schunck ${ }^{17}$ praat van 'n besliste breuk met die hede en die aanbreek van 'n totaal nuwe bedeling. Die beklemtoning van die nuwe kom ook by Vriezen voor. Hy praat van 'n "neues Königreich" en "neue Welt" en bedoel daarmee dinge wat binne die geskiedenis verwag kan word. Gowan ${ }^{18}$ beklemtoon in sy poging tot 'n definisie van eskatologie die diskontinuïteit tussen die hede en toekoms met die daarmee gepaardgaande transformeringsprosesse. Die verwagting dat God 'n drievoudige transformasie teweeg sal bring, hoort vir Gowan tot die wesenlike van die eskatologie in die Ou Testament. God sal die mens, die gemeenskap en die natuur transformeer. Die "transformed future" word deur Gowan eskatologie genoem. Daarmee word met ander woorde die aspek van die nuwe na vore gebring. Vir Preuss ${ }^{19}$, wat veel klem lê op die koms van Jahwe as basiese element van die eskatologie, beteken eskatologie "ein neues Kommen und Handeln des Gottes Israels". Vir Von Rad ${ }^{20}$ gaan dit in die eskatologie om die "new action of Jahwe in history".

Die profete was van oortuiging dat Jahwe Israel met 'n nuwe daad sou ontmoet. Tussen die oue en die nuwe is die breuk van so 'n aard dat die nuwe onmoontlik as die voortsetting van die oue verstaan sou kon word. Dit is kenmerkend van die profetiese eskatologie dat die oordeelstema sterk figureer. Die oordeel word so geformuleer dat dit die radikaliteit van die oorgang van die oue tot die nuwe beklemtoon. Sowel die finaliteit waarmee die ou tydvak tot 'n einde kom as die noodsaaklikheid dat die oue beëindig moet word, kom in die radikale oordeelsaankondiginge tot uitdrukking. Daar bestaan daarom by die profete ' $n$ baie noue band tussen oordeelsprediking en eskatologie.

\section{Restouratiewe handeling van Jahwe}

Die analogie waarmee die nuwe beskryf word bring 'n volgende element na vore wat oorweeg moet word en dit is die restouratiewe. Dit is belangrik om daarop te let dat daar te midde van die verwagting van 'n totaal nuwe tyd, wat nie as die voortsetting van die oue gesien kan word nie, tog 'n analogie tussen die oue en die nuwe bestaan. Die nuwe word inhoudelik deur die oue bepaal, selfs al is dit geheel 
en al nuut. Die beskrywing van die "nuwe" is nie uit die lug gegryp nie, maar analoog tot die heilshandeling van Jahwe in die verlede. Von $\mathrm{Rad}^{21}$ verwys na temas soos nuwe intog (Hosea), nuwe Dawid en nuwe Sion (Jesaja), nuwe verbond (Jeremia) en die nuwe uittog by Deuterojesaja wat daarop dui dat die profete hulle anders as vroëer nou aan die toekoms oriënteer. Die analogie met die verlede is egter duidelik. Le Roux 22 verwys hierna as "the dualistic approach of the prophets towards the old picture of salvation history". Die heilshandeling van Jahwe in die verlede het die model en die begrippemateriaal verskaf aan die hand waarvan die eskatologiese verwagtinge geformuleer is. Die afvalligheid van die volk en die gepaardgaande oordeel deur Jahwe vorm die agtergrond waarteen die verwagting dat Jahwe met 'n geheel en al nuwe tyd sal begin, verstaan moet word. Die nuwe daad van Jahwe het die herstel van die ou verhouding tussen Hom en die volk ten doel.

Die aspek van finaliteit in die Jahwehandeling

'n Aspek wat ten nouste saamhang met die verwagting van 'n nuwe tydvak en wat verder as een van die kenmerke van eskatologie geld, is die beklemtoning van finaliteit. Die ingrype van Jahwe is beslissend. Von Rad noem dit een van die konstituerende elemente van die profetiese eskatologie. Müller ${ }^{23}$ bou sy hele uiteensetting van die eskatologie om die begrip "Endgültige". Vir Preuss ${ }^{24}$ is die "Kommen Jahwes" deurslaggewend om te bepaal wat as eskatologies gereken kan word. Hy beklemtoon dat dit in die eskatologie gaan om die "Endgültigen" koms van Jahwe.

\section{Jahwehandeling in die konkrete werklikheid}

By die bespreking van die problematiek van die terminologie (vgl 1) is reeds gewys op die belangrikheid daarvan om die eskatologie in die Ou Testament nie te verplaas na gebeure aan die einde van die tyd nie, maar dit as deel van historiese prosesse te probeer verstaan. Gowan 25 lys die "wordly hope" as een van die kenmerke van die Ou-Testamentiese eskatologie.

Die verwagting was dat die nuwe dinge wat finaal met die koms van Jahwe 'n werklikheid sal word, iets is wat in die konkrete werklikheid realiseer. "Kenzeichend für die atl. Auffassung ist vor allem, dass die eschatologische Erwartung an die Geschichte gebunden is, ja die Eschatologie bestimmt deren Verlauf, führt sie zur Erfüllung und begabt sie mit Sinn"26. 


\section{'n Definisie van eskatologic}

Met die aanbied van 'n definisie word 'n afspraak gemaak oor wat met die begrip eskatologie in hierdie artikel bedoel word.

Eskatologie verteenwoordig die perspektief op die toekoms waarin Jahwe self die ou tydvak deur oordeel tot ' $n$ einde bring en 'n nuwe tydvak in die geskiedenis tot stand bring.

\section{ESKATOLOGIE IN DIE BOEK SEFANJA}

'n Analise van die verskillende tekseenhede in die boek Sefanja lewer die volgende resultate met betrekking tot die tema eskatologie:

\subsection{Jerusalem as fokuspunt van die eskatologiese verwagting}

Die stad Jerusalem vorm ' $n$ fokuspunt in die boek Sefanja. Daar is 'n tendens in die navorsing om die Jom Jahwe as die dominante tema van die boek Sefanja te beskou. In die behandeling van dié tema sal aangetoon word dat hierdie opvatting in hoofsaak korrek is, maar dat dit nodig is om uit te wys dat die Jom Jalıwe in die boek Sefanja ten nouste met die stad Jerusalem verbind is. Die oordeelsuitsprake in die eerste komposisie (Sef 1:2-3:8) is wesenlik 'n veroordeling van die stad Jerusalem. Dit is wel so dat daar ook van die volk melding gemak word, maar die oordeelswoorde vertoon ' $n$ besondere konsentrasie op Jerusalem. Dit is reeds uit Sefanja 1:2-6 duidelik dat Jerusalem 'n prominente plek inneem. In Sefanja 1:4 het die woorde מן־המקום הוצה op Jerusalem betrekking. Omdat dit dikwels weens metrumoorwegings geskrap word, gaan 'n belangrike fokuspunt in die teks verlore. In die tweede eenheid (Se 1:7-13) word die Jom Jahwe as die oordeel van Jahwe oor die stad Jerusalem beskryf. In die derde eenheid van Komposisie 1 (Sef 1:1416) is daar nie so 'n opvallende klem op die stad nie, maar in die uitdrukkings in 1:16 is die tema beleëring van die stad wel teenwoordig. Die fokus op die stadtema is ook in Sefanja 2:4-3:8 opvallend. Die stad Jerusalem is deur die verbinding van Sefanja 3:1-5 met Sefanja 2:4-15 op dieselfde vlak as die ander stede geplaas. Die toneel van die verwoeste stad word gebruik om die uitwerking van die oordeel van Jahwe te beskryf.

In die tweede komposisie vind ons 'n soortgelyke fokus op die stad Jerusalem. In Sefanja 3:9-11 word die naam Jerusalem nie genoem nie, maar die bekende Völkerwallfahrt-tema na Jerusalem kom voor. Sefanja 3:11-13 is ook tot Jerusalem gerig en word skerp met die oordeelswoord oor Jerusalem in Sefanja 3:1-5 
gekontrasteer. Sefanja 3:14-17 beskryf in die styl van die Aufruf zur Freude die vreugde oor die teenwoordigheid van Jahwe in Jerusalem.

Indien al die gegewens met betrekking tot die funksie van Jerusalem in die boek Sefanja saamgelees word, is dit duidelik dat dit hier as 'n eskatologiese simbool funksioneer. Die verskillende elemente wat eie aan eskatologie is, vind in die uitsprake oor Jerusalem uitdrukking.

In die poging om 'n definisie vir eskatologie te formuleer, is daarop gewys dat die verwagting van 'n nuwe tydvak 'n konstituerende element is. Die boek Sefanja handel op so 'n wyse oor Jerusalem dat 'n kontras tussen die ou en nuwe Jerusalem duidelik waarneembaar is. Die begrippe oud en nuut gee goeie uitdrukking aan die twee beelde van Jerusalem in die boek Sefanja. Die kontras tussen die Jerusalem van die eerste komposisie (Sef 1:2-3:8) en dié van die tweede komposisie (Sef 3:9-3:20) is van so 'n aard dat daar met goeie reg van 'n ou en nuwe Jerusalem gepraat kan word. Waar die oordeel in die eerste komposisie ten nouste aan die stad Jerusalem verbind word, word die heil in Komposisie 2 ook aan Jerusalem verbind. Deur middel van doelbewuste kontrasvorming word daar dus twee beelde van Jerusalem in die boek Sefanja geskets. Die een verteenwoordig die ou tydvak wat deur Jahwe tot 'n einde gebring word en die ander die nuwe tydvak wat eweneens deur Jahwe bewerkstellig word. Indien die twee beelde van Jerusalem langs mekaar geplaas word, blyk die element van diskontinuïteit baie duidelik.

Die transformering van die ou Jerusalem tot die nuwe is volledig die werk van Jahwe. Die beëindiging van die ou tydvak is die resultaat van Jahwe se oordeelshandeling. Die transformering van Jerusalem is toe te skryf aan Jahwe wat die hoogmoedige uit die stad verwyder en deur sy teenwoordigheid 'n totaal nuwe karakter aan Jerusalem gee. Die feit dat die oorlogsgeraas deur die jubellied vervang kan word, is aan die betrokkenheid van Jahwe te danke. Die aksent op die beslissende rol wat Jahwe met betrekking tot die transformering van Jerusalem speel, bevestig weer eens dat dit in die eskatologie om 'n "Jahweerwartung"27 gaan. Dit is die terugkoms van Jahwe wat dit moontlik mak om weer van "my heilige berg" (3:11) te praat. Die koms van die heilstyd "hängen nicht von der ethischen Bewährung der Bevölkerung ab, sondern sie sind Folgen der gnadenhaften Gegenwart Jahwes auf dem Zion"28. Hierdie persoonlike karakter is kenmerkend van die eskatologie in die boek Sefanja.

Die twee beelde van Jerusalem wys weliswaar op 'n radikale diskontinuiteit tussen die oue en die nuwe. Die fokus op die stad Jerusalem verteenwoordig egter ook die restouratiewe karakter van eskatologie in die sin dat daar tog 'n analogie tussen die oue en die nuwe bestaan. Die kontras tussen Komposisie 1 en 2 het dus die funksie dat dit tegelyk die elemente van diskontinuïteit en analogie na vore bring. Die eskatologisering van die Sionstradisie beteken dat daar met 
gebruikmaking van die ou en bekende begrippemateriaal, wat met Jerusalem verbind is, 'n nuwe tydvak beskryf word.

Die aspek van finaliteit kom ook in die fokus op Jerusalem na vore. Sowel die oordeelswoord as die daaropvolgende heilswoord vertoon 'n "endgültige" karakter. In die analise van die oordeelswoorde in Komposisie 1 is telkens op die radikale aard daarvan gewys. Omdat sowel die heil as die oordeel aan die optrede van Jahwe verbind is, het die eskatologiese verwagting met sy fokus op Jerusalem die karakter van onomkeerbaarheid, oftewel finaliteit.

'n Kenmerkende aspek van Ou-Testamentiese eskatologie is dat dit deel vorm van die historiese prosesse. Nog die oordeel nog die heil, soos wat dit in die boek Sefanja verwoord word, het iets met die "einde van die tyd" te make. Dit gaan oor verwagtinge wat in die konkrete werklikheid gerealiseer moet word.

Die korporatiewe aard van Ou-Testamentiese eskatologie vind ook in die fokus op Jerusalem uitdrukking. Hier is nêrens sprake van indiwiduele eskatologie nie. Die oordeel en die heil het 'n korporatiewe karakter en word aan Jerusalem, wat sigself daartoe leen om simbool van die volk te wees, verbind.

In bogenoemde ontleding van die plek wat Jerusalem in die boek Sefanja inneem, is aangetoon dat verskeie van die elemente wat kenmerkend van eskatologie is, in die boek Sefanja aangetref word.

\subsection{Die Jom Jahwe as eskatologiese tema}

Dit word algemeen aanvaar dat die Jom Jahwe die sentrale tema van die boek Sefanja is ${ }^{29}$. Ook Edler ${ }^{30}$ beskou dit as die "beherrschende Tema" in die profeet Sefanja se verkondiging terwyl Robertson ${ }^{31}$ die Jom Jahwe uitsonder as dié tema waarmee die verskillende gedeeltes in die boek aan mekaar verbind word. By 2.1 is aangetoon dat die stad Jerusalem eerder as die samebindende faktor in die boek beskou moet word. Dit beteken egter nie dat die Jom Jahwe nie 'n belangrike tema in die boek is nie. Inteendeel, behalwe vir die gedeeltes waar die term יום יהרוה voorkom (Sef 1:7-13; 14-18), toon 'n analise van hoofstuk drie aan dat die tema ook in dié hoofstuk deur middel van kontrasvorming aan die orde is. Alhoewel die stad Jerusalem die fokuspunt in die boek is ( $\mathrm{vgl} \mathrm{2.1)}$ speel die Jom Jahwe tog 'n baie belangrike rol. Sowel die oordeel as die heil word deur middel van die Jom Jahwe verwoord.

Vir die doel van hierdie artikel is slegs probeer om vas te stel watter rol die Jom Jahwe met betrekking tot eskatologie in die boek Sefanja speel. Dit is 'n vraag wat telkens in die navorsing oor die Jom Jahwe opduik. Verskillende antwoorde word hierop gegee. Die Jom Jahwe word deur sommige geleerdes volledig met die eskatologie verbind. Gressman se vormkritiese ondersoek na die 
oorsprong van die "israelitisch-jüdischen" eskatologie is 'n goeie voorbeeld hiervan. Gressman onderskei tussen Unheilseschatologie en Heilseschatologie wat veel ouer as die profetiese literatuur is en sy oorsprong buite Israel in die Babiloniese mitologie gehad het. Die Jom Jahwe het volgens hom die kern van die Unheilseschatologie uitgemaak en moet as vaste eskatologiese term beskou word 32 . Sedert Gressmann se publikasie in 1905 oor die eskatologie is lank algemeen aanvaar dat die Jom Jahwe uitsluitlik met die toekoms te make het. Die Jom Jahwe is as "das Kernstück der prophetischen Eschatologie" gereken ${ }^{33}$. Everson ${ }^{34}$ toon egter oortuigend aan dat hierdie eksklusiewe verbintenis van die Jom Jahwe met gebeure in die toekoms nie opgaan nie, omdat die begrip ook gebruik kan word om gebeure in die verlede te beskryf. Hy verwys na vyf voorbeelde waar die Jom Jahwe gebeure in die verlede beskryf. Klaagliedere 1 en 2, is soos Esegiël 13:1-9, 'n terugblik op die val van Jerusalem in 587 vC, Jeremia 46:2-12 na Karkemis in 605 vC en Jesaja 22:1-14 verwys na die inval van Sanherib in 701 vC. Volgens Everson 35 (1974:335) was die Jom Jahwe 'n kragtige konsep waarmee die profete "past, future or imminent" gebeure kon interpreteer.

Teenoor die tendens waarin die Jom Jahwe volledig in die eskatologie opgaan, is daar die ander uiterste waarin enige verband tussen die Jom Jahwe en eskatologie ontken word. So byvoorbeeld beskou Herrmann ${ }^{36}$ die Jom Jahwe as "kein eschatologischer Begriff, sondern eine Umschreibung des Machtpotentials Jallwes." Vir Herrmann gaan dit dus nie in die eerste plek om tydskategorieë nie, want die Jom Jahwe het volgens hom 'n gebeurekarakter. Dit is nie 'n tydstip in die toekoms wat ter sake is nie, maar "das Wirken Jahwes". Die benadering van Herrmann moet as 'n reaksie op die ongenuanseerde gelykstelling van die Jom Jaliwe en eskatologie verstaan word. Dit is egter belangrik om daarop te let dat Herrmann wel ruimte laat vir 'n "zeitliches Moment". Die werksaamheid van Jahwe realiseer binne 'n tydsruimte. Dit het 'n "Anfang und Ende". Alhoewel Herrmann se aksent op die gebeurekarakter van die Jom Jahwe ter sake is, kan dit nie ontken word dat die tema wel binne die kader van die eskatologie benut word nie. Preuss ${ }^{37}$ slaag goed daarin om die nie-eskatologiese en eskatologiese karakter van die Jom Jahwe met mekaar in verband te bring. Hy wys daarop dat die verwagting soos uitgedruk in die Jom Jahwe nie as "Vorläufer" van die eskatologie gesien moet word nie, maar eerder as "Mitlăufer". Daarmee bedoel hy, in aansluiting by Schunck ${ }^{38}$, dat die Jom Jahwe in eskatologiese en nie-eskatologiese verband voorkom. Schunck onderskei twee groot "Strukturlinien" wat uit 'n gemeenskaplike wortel ontwikkel het, naamlik "eine eschatologische und eine nicht-eschatologische Linie".

Die benadering wat rekening hou met die feit dat die Jom Jahwe 'n ontwikkeling deurgemaak het en dat dit nie 'n eenduidige betekenis het nie, laat reg geskied aan die verskillende kontekste waarbinne die Jom Jahwe funksioneer. Die 
implikasie is dat die Jom Jahwe in sommige tekste eskatologies verstaan moet word en in ander nie. Die boek Sefanja is 'n voorbeeld waar die Jom Jahwe wel in 'n eskatologiese verband voorkom.

In Sefanja 1:7-13 en 1:14-16 vertoon die oordeel 'n omvattende karakter. Daar is nie sprake van 'n selektiewe oordeel nie. Deur middel van die tegniek van meerduidige aanwending van woorde word in dié gedeeltes daarin geslaag om die boodskap oor te dra dat almal onder die oordeel staan. Die antropomorfiese wyse waarop Jahwe voorgestel word as die een wat Jerusalem met lampe deursoek, wys ook op die omvattendheid van sy oordeel en is as sodanig tipies van die eskatologie.

Dit is bepalend vir die vraag na die eskatologiese karakter om vas te stel tot in watter mate 'n nuwe tydvak verwag word. Die verwagting van 'n nuwe tydperk is op sy beurt weer onlosmaaklik verbind aan die oortuiging dat die oordeel oor die huidige tyd so radikaal is dat dit nie langer kan voortgaan nie: "Because Yahweh was coming and would create something new, the present age must perish"39. Hiermee saam is die verwagting van 'n nabye koms van Jahwe kenmerkend van die eskatologiese verwagting van die profete. In die analise van die gedeeltes waarin die Jom Jahwe prominent voorkom, is die voorkoms van 'n omkeringstendens opvallend. Die suggestie van die positiewe word opgevolg deur negatiewe oordeelsaankondiging. Die omvorming van iets so positief soos die اבח-maaltyd tot 'n slagting wat deur Jahwe beplan word, bevestig dat die ou heilsekerheid beëindig word. Hoe die aankondigingsformule met betrekking tot die Jom Jahwe ook al verstaan word, dit dui in elke geval op die verwagting dat Jahwe binnekort sal ingryp en die ou dinge tot niet sal maak. In die Jom Jahwe aankondiging word gestalte gegee aan die oortuiging dat die oue nie langer kan bly voortbestaan nie. Deur middel van die tegniek van satire en gepaardgaande karikatuurbeelding word beklemtoon dat dit ondenkbaar is dat die huidige toestand kan voortduur. Die satiriese toon bevestig dat dit "belaglik" sou wees om te dink dat dit moontlik kon wees. Sodoende word die basis gelê vir die verwagting dat daar 'n geheel en al nuwe tydvak moet aanbreek. Dit is daarom geen verrassing dat die beskrywing van die heil in die tweede komposisie in skerp kontras met die oordeel van die eerste komposisie staan nie. Die radikale diskontinuiteit tussen die oue en die nuwe word daarmee treffend gekommunikeer.

In die beskrywing van die kenmerke van die eskatologie wat by die profete voorkom, is daarop gewys dat Jahwe self sentraal in die eskatologiese verwagting staan. Die beskrywing van die Jom Jalıwe is hiervan 'n goeie voorbeeld. Daar word deurgaans ' $n$ besondere klem op die handeling van Jahwe in die konkrete werklikheid geplaas.

Dit is geregverdig om, in die lig van die voorkoms van verskeie elemente wat kenmerkend van eskatologie is, te aanvaar dat die Jom Jahwe in die boek 
Sefanja deel uitmaak van 'n eskatologiese verwagting. Waar die Jom Jahwe in 'n oordeelskonteks gebruik word, het dit die funksie dat dit Israel losskud van "the safety of the old saving actions"4). In die tweede komposisie word daar deur middel van kontrasskepping op die Jom Jahwe van die eerste komposisie gesinspeel. Die Jom Jahwe verwys primêr na die oordeel van Jahwe, maar aangesien dit die radikale beëindiging van 'n era beskryf, open dit die deur vir die formulering van 'n nuwe verwagting met betrekking tot 'n tyd waarin die heerskappy van Jahwe volledig erken sal word.

\subsection{Die volke en eskatologie}

Die tema van die volke speel 'n prominente rol in die profetiese eskatologie. Kenmerkend van die "Grundzüge" van eskatologie is onder andere die twee temas van die vernietiging en die verlossing van die volke. Die twee temas is verteenwoordigend van die twee pilare van die profetiese eskatologie, naamlik die oordeelseskatologie en die heilseskatologie. In die boek Sefanja is albei temas duidelik waarneembaar. In die eerste komposisie (Sef 1:2-3:8) is die oordeelsuitsprake oor die volke in 2:4 redaksioneel aan die Jom Jahwe-tema verbind terwyl die heilswoord in Komposisie 2 (Sef 3:9-20) ook ten opsigte van die volke geld. Die tema van die volke pas goed by die universele beklemtoning van die boek in. Sowel die oordeelseskatologie as die heilseskatologie is universeel. Soos by die uitsprake met betrekking tot Jerusalem bestaan daar ook twee voorstellings ten opsigte van die volke. Die volke kom ook onder die radikale oordeelswoord van Jahwe te staan. Hy sal 'n einde maak aan die hoogmoedige volke wat spottend teenoor Hom staan, maar tog sal Hy aan die volke rein lippe gee sodat hulle Hom in eensgesindheid kan dien. In dié opsig is die grondliggende eskatologiese struktuur van die boek Sefanja sigbaar. Die verwagting dat Jahwe self die oue sal beëindig en die nuwe in die plek daarvan sal stel, is dus nie net op Jerusalem van toepassing nie. Dit geld ook vir die volke.

Die plek wat die volke in die eskatologie by Sefanja inneem, bevestig ook die korporatiewe karakter wat tipies van die eskatologie by die profete is. Daar is nie sprake van 'n individuele eskatologie nie. In die boek Sefanja word die oordeel en die heil in 'n universele raamwerk geplaas. In die eerste komposisie word die Jom Jahwe met sy besondere toespitsing op Jerusalem deur twee universele gedeeltes omraam. Daardeur kry die Jom Jahwe in Sefanja 'n universeel-eskatologiese karakter. Die totale kosmiese werklikheid is by die eskatologiese verwagting betrokke. 
Hase $\mathrm{l}^{41}$ het oortuigend aangetoon dat die terminologie rondom die oorblyfseltema 'n "bi-polarity" vertoon wat van deurslaggewende belang in die verstaan van die konsep is. Hy wys ook daarop dat elke konteks afsonderlik beoordeel moet word om vas te stel watter aksent in die betrokke konteks dominant is. Die "bi-polarity", wat so inherent deel is van die oorblyfselmotief, val in die boek Sefanja met die eskatologiese grondstruktuur van die boek saam. Die elemente van diskontinuiteit en kontinuïteit, wat van besondere belang in die besinning oor eskatologie is, is 'n wesenlike deel van die oorblyfseltema. Dit beteken dat die gegewens in die boek Sefanja 'n bydrae kan maak in die gesprek oor eskatologie waarin ekstrapolasie (Berkhoff) en antisipasie (Moltmann) in die een of ander balans tot mekaar moet funksioneer. Die hoog aangeskrewe Jerusalem word tot 'n onbeduidende oorblyfsel gereduseer (oordeel), maar die oorblyfsel waarborg die moontlikheid van 'n nuwe begin. Alhoewel die element van oordeel teenwoordig is, lê die aksent in die boek Sefanja op die positiewe inhoud van die oorblyfselmotief. In dié begrip val kontinuïteit en diskontinuïteit saam. Hoe sterk ook al die beklemtoning van die diskontinuïteit, die kontinuiteit bly behoue. "Daarbij is te bedenken, dat in dit begrip hoop en wanhoop verenigd zijn en dat 'rest' ook en zelfs vooral wil zeggen: na het gericht zal er weer een toekomst zijn"42. Gemeet aan die beskrywing van eskatologie in hoofstuk 1 funksioneer die oorblyfselmotief in die boek Sefanja dus as 'n eskatologiese begrip. Dit bevat die element van radikale beëindiging van 'n era asook die verwagting van 'n nuwe heilstyd. Die ontstaan en uiteindelike lot van die oorblyfsel is volledig aan die handeling van Jahwe toe te skryf.

\subsection{Eskatologie en etiek}

Die eskatologie in die boek Sefanja het 'n oordeelskomponent en 'n heilskomponent wat met mekaar verbind is. In albei gevalle is bevind dat daar 'n verband tussen eskatologie en etiek bestaan. Die hede en die toekoms is binne die eskatologiese perspektief ten nouste met mekaar verbind. Die oordeelsaankondiging vloei voort uit die huidige gedrag van Israel. Daar is 'n interafhanklikheid tussen toekomsverwagting en sosiale kritiek. $\mathrm{Nicol}^{43}$ merk tereg op dat dié twee aspekte "mekaar oor en weer voed". Omdat daar die oortuiging bestaan het dat Jahwe as "Allherr" in die geskiedenis gaan ingryp, word die maatskappy telkens aan die wil van Jahwe gemeet. Omdat die eskatologie nie 'n los aanhangsel tot die Jahwegeloof is nie, maar wesenlik deel daarvan is, kon die profete die samelewing krities beskou en het hulle nie in 'n status quo-denkpatroon vasgeval nie. Binne die Jahwegeloof was dit moontlik en noodsaaklik om 'n nuwe daad van Jahwe te verwag. Die profetiese 
kritiek op die misstande in die samelewing staan dus nie los van die eskatologie nie. Die eskatologie is ook nie 'n wegvlug die toekoms in nie. Maatskappykritiek vloei dus voort uit die eskatologie.

In sy sterk beklemtoning van die eskatologie, wat wesenlik deel van die "Jahweglaube" is, ontken Preuss ${ }^{44}$ dat die eskatologie selfs net ten dele aan die spanning tussen ideaal en werklikheid toegeskryf kan word. Dat so 'n spanning 'n rol in die eskatologie speel, kan egter nie ontken word nie. In die boek Sefanja is daar 'n sterk wisselwerking tussen eskatologie en maatskappykritiek. Die toekomsgerigtheid, wat so tipies van die Ou Testament is, is ten dele ook aan die bestaan van maatskaplike onreg toe te skryf. Alhoewel Nicol die boek Sefanja "slegs in die verbygaan noem", bevestig die boek sy basiese uitgangspunt van 'n wisselwerking tussen maatskappykritiek en eskatologie. Dat die samelewing in al sy gestaltes in die eenheid onder bespreking skerp gekritiseer word, het duidelik uit die bespreking van die eenheid waarin die oordeel uitgespreek word, geblyk. Met skerp spot en ironie word die sonde van die inwoners van Jerusalem op kultiese en sosiaal-politiese terrein uitgewys. Niemand of niks word gespaar nie. Met so 'n gemeenskap kan Jahwe nie verder gaan sonder om iets radikaal nuut te doen nie. Die feit dat Jahwe die een is van wie verwag kon word om iets nuuts te doen stimuleer egter ook die profetiese kritiek op die gemeenskap. Die ideale eskatologiese gemeenskap wat in die tweede komposisie in die vooruitsig gestel word, lewer ook indirek kritiek op onreg. Die kontras tussen die ideale gemeenskap en die werklike gemeenskap is in die boek Sefanja besonder prominent. Die beskrywing van die eskatologiese gemeenskap dien as maatstaf aan die hand waarvan die werklike gemeenskap homself moet meet.

\subsection{Gevolgtrekking}

Die boek Sefanja verteenwoordig 'n toekomsperspektief waarin Jahwe self die ou tydvak deur oordeel tot 'n einde sal bring en 'n nuwe tydvak in die konkrete werklikheid tot stand sal bring wat die heil beslissend sal realiseer. In die beskrywing van die aard van die eskatologie in die Ou Testament moet die boek Sefanja met sy kenmerkend eskatologiese karakter 'n prominenter plek inneem. Die resultate van die studie bevestig die voorkoms van 'n bepaalde soort toekomsverwagting wat in onderskeid van ander vorme met die term eskatologie beskryf kan word. 


\section{NOTAS:}

$1 \quad$ Hierdie artikel gee 'n samevatting van 'n proefskrif wat voltooi is onder leiding van prof W S Prinsloo, Departement Ou Testament, Universiteit van Pretoria.

2 H Gressmann, Der Ursprung der israelitisch-judischen Eschatologie, Göttingen $1905,1$.

3 Th C Vriezen, Prophecy and eschatology, Darmstadt 1953, 202.

4 G Wanke, "Eschatologie. Ein Beispiel theologischer Sprachverwirrung", in: H

D Preuss (Hg), Eschatologie im Alten Testainent, Darmstadt 1978, 343.

5 H D Preuss, Eschatologie im Alten Testament, Darmstadt 1978.

$6 \quad$ P Althaus, Die lezten Dinge, Gutersloh 1933, 1.

7 G von Rad, Old Testament Theology, Vol II, London 1965, 114-115.

8 H D Preuss, Jahweglauhe und Zukunftsenwartung, Stuttgart 1968, 207.

9 So byvoorbeeld S Herrmann, Die prophetische Heilserwartungen im Alten Testament, Stuttgart 1965.

$10 \quad$ Von Rad, $a w, 113$.

11 Vergelyk vir 'n oorsig J H le Roux, "Eschatology and the prophets (A survey of the research)", OTE NS 1(1) 1988, 1-26.

12 H D Preuss, $a w, 1968,206-207$.

13 T M Raiit, $A$ theology of exile. Judgement/deliverence in Jeremiah and Ezekiel, Philadelphia 1977, 217.

14 J Lindblom, "Gibt es eine Eschatologie bei den alttestamentlichen Propheten?" Studia Theologica (6) 1952, 79-114.

15 H Gross, "Eschatologie im Alten Bund", Anima 20 (1965), 213-219.

16 F Dingermann, "Israels Hoffnung auf Gott und sein Reich", in: H D Preuss, Eschatologie im Alten Testament, 1967(1978), 239.

17 K D Schunck, "Strukturlinien in der Entwicklung der Vorstellung vom 'Tag Jahwes'" in: Preuss, $a w, 1978,467$.

18 D E Gowan, Eschatology in the Old Testament, Philadelphia 1986, 1-3.

19 H D Preuss, $a w, 1968,207$. 
20 Von Rad, $a w, 1965,113$.

$21 \quad$ Von Rad, $a w, 117$.

22 Le Roux, $a w, 8$.

23 H Muller, Ursprunge und Strukturen alttestamentlicher Eschatologie, Berlin 1969.

24 Preuss, $a w, 1968,207$.

25 Gowan, $a w, 122$.

26 H Gross, $a w, 184$.

27 Preuss, $a w, 1968,206-207$.

28 W Werner, Eschatologische Texte in Jesaja 1-39, Würzburg 1982, 156 met verwysing na Jesaja 2:2.

29 So byvoorbeeld by W S Prinsloo, "Die boek Sefanja", in: J J Burden \& W S Prinsloo, (reds) Tweegesprek met God. Predikers, digters en wysgere, Kaapstad 1987, 285. Kyk ook A S van der Woude, Habakuk Sefanja, Nijkerk 1978, 8283 en P A Verhoef, Die Dag van die Here, Den Haag 1956, 46.

30 R Edler, Das Kerygma des propheten Zefanja, Freiburg 1984, 249.

31 O P Robertson, The books of Nahum, Habakkuk and Zephaniah, Grand Rapids 1990, 257.

32 Gressmann, $a w, 31$.

33 Schunck, $a w, 320$.

34 A J Everson, The days of Yahweh as historical event: A study of the historical and theological purposes for the employment of the concept in the classical prophets of the Old Testament, Ann Arbor 1969, 50-119.

35 Everson, $a w, 335$.

36 Herrmann, $a w, 112$.

37 Preuss, $a w, 179$.

38 Schunck, $a w, 319$.

39 Le Roux, $a w, 3$.

$40 \quad$ Von Rad, $a w, 118$.

41 G F Hasel, The origin and early history of the remnant motif in ancient Israel, 
Ann Arbor $1970,457$.

42 H Berkhoff, Christelijk geloof, Nijkerk 1975, 258.

43 W Nicol, Die betekenis van die eskatologie vir die sosiale etiek, Pretoria 1984, 9.

44 Preuss, $a w, 1968,210$. 